\title{
Translation and Adaptation of the Trier Social Stress Test for Children into Portuguese Language
}

\author{
Thiago Wendt Viola \\ Luis Eduardo Wearick-Silva \\ Saulo Gantes Tractenberg \\ Rodrigo Grassi-Oliveira ${ }^{1}$ \\ Centre of Studies and Research in Traumatic Stress, Pontifical Catholic University \\ of Rio Grande do Sul, Porto Alegre, Brazil
}

\begin{abstract}
Since the 1990s there have only been a few studies with human subjects that focused on the underlying mechanisms associated with acute psychological stress exposure and even less have been conducted with children. Based on the idea that it is possible to elicit and measure behavioral and physiological patterns in response to stressors in a short period of time, the Trier Social Stress Test (TSST), an experiment that consists of public speaking exposure and a mental arithmetic task, was developed. However, there is no Brazilian version of the TSST for children. The current study sought to translate and adapt the TSST protocol for children to the Brazilian Portuguese language. The final version of the adapted protocol consists of a story regarding the public speaking phase, as well as instructions about each phase of the protocol, including the rapports and information concerning the pre- and the post-stages of the TSST for children. This work is building toward innovation in the Brazilian stress research field. In addition, whereas research on stress also involves physiological and biological markers measurements, the TSST is also an innovative tool for multidisciplinary research.
\end{abstract}

Keywords: Experimental psychology, children, physiological stress, psychological stress, anxiety, allostasis.

\section{Tradução e Adaptação do Trier Social Stress Test para Crianças para o Português}

\section{Resumo}

Antes da década de 1990, poucos estudos com sujeitos humanos focaram-se nos mecanismos subjacentes associados à exposição ao estresse psicológico agudo e, ainda menos, foram conduzidos em amostras infantis. Baseando-se na ideia de que é possível eliciar e medir padrões comportamentais e fisiológicos em resposta a estressores em um curto período de tempo, o Trier Social Stress Test (TSST), um experimento que consiste na exposição à fala em público e a uma tarefa mental aritmética, foi desenvolvido. Todavia, não existe versão brasileira para o TSST aplicável a crianças. Assim, o presente estudo objetivou traduzir e adaptar para a língua portuguesa do Brasil o protocolo do TSST para crianças. A versão final do protocolo adaptado consiste na história narrada na fase de fala em público, bem como em ins-

Mailing address: Biomedical Research Institute, Centre of Studies and Research in Traumatic Stress, Pontifical Catholic University of Rio Grande do Sul, Av. Ipiranga, 6681, prédio 11, sala 936, Porto Alegre, RS, Brazil 90619-900. E-mail: thiago.viola@acad.pucrs.br, dudu8a@hotmail.com, saulotractenberg@hotmail.com and rodrigo.grassi@pucrs.br 
truções sobre cada fase do protocolo, incluindo rapports e informações sobre as fases pré e pós TSST. Este trabalho visa à inovação no campo de pesquisas brasileiro sobre estresse. Além disso, enquanto a pesquisa sobre estresse também envolve medições de marcadores fisiológicos e biológicos, o TSST é também uma ferramenta inovadora para a pesquisa multidisciplinar.

Palavras-chaves: Psicologia Experimental, crianças, estresse fisiológico, estresse psicológico, ansiedade, alostase.

\section{Traducción y Adaptación del Trier Social Stress Test para Niños en Lengua Portuguesa}

\section{Resumen}

Antes de la década de 1990, pocos estudios con sujetos humanos se han centrado en los mecanismos subyacentes asociados con la exposición al estrés psicológico agudo, y aún menos se llevaron a cabo en muestras de niños. Basándose en la idea de que es posible para obtener y medir los patrones fisiológicos y de comportamiento en respuesta a factores estresantes en un período corto de tiempo, la Prueba de Estrés Social Trier (TSST), un experimento que consiste en la exposición a hablar en público y tarea mental aritmética, fue desarrollado. Sin embargo, no hay versión brasileña del TSST aplicable a los niños. Por lo tanto, el presente estudio tuvo como objetivo traducir y adaptar el protocolo del TSST para los niños al portugués del Brasil. La versión final del protocolo se adaptó la historia narrada en la fase de hablar en público, así como las instrucciones para cada fase del protocolo, incluyendo rapports e información acerca de la TSST pre y post. Este trabajo tiene como objetivo innovar en el campo de los estudios brasileños sobre el estrés. Por otra parte, mientras que la investigación sobre el estrés también involucra mediciones de marcadores biológicos y fisiológicos, la TSST es también una herramienta innovadora para la investigación multidisciplinaria.

Palabras claves: Psicología experimental, niños, estrés fisiológico, estrés psicológico, ansiedad, alostasis.

Psychological stress can be defined as a constellation of events, consisting of a stimulus (stressor) that precipitates a reaction in the brain (stress perception) and activates physiological fight or flight systems in the body (stress response; Dhabhar, 2013). The consequences of psychological stress exposure have been the focus of numerous studies (Galvan \& Rahdar, 2013; Grassi-Oliveira, Ashy, \& Stein, 2008; McEwen, 2012; Yehuda \& Seckl, 2011). In addition, there is mounting evidence supporting that psychological stress might induce cognitive, emotional, and biological changes that resemble those elicited by physical stressors (Cirulli et al., 2009; Danese \& McEwen, 2012; Dickerson \& Kemeny, 2004). Nevertheless, since 1990s, only a few studies have been conducted with human subjects that focused on the underlying mechanisms associated with acute psychological stress exposure, and even less have been conducted with children. Some studies (Ackerman, Martino, Heyman, Moyna, \& Rabin, 1996; Al'Absi et al., 1997; Cacioppo et al., 1995), therefore, have been done in order to increase the accuracy of stress-induced experimental methods over the last two decades.

Researches brought to human studies experimental paradigms of stress inoculation that were first used on animal models (e.g., exposure to electrical shock, exposure to high-pitched sounds, maternal separation, etc.), based on the idea that it is possible to elicit and measure behavioral and physiological patterns in response to stressors in a short period of time (Dickerson \& Kemeny, 2004). Such experiments were already quite successfully employed in research with rodents and primates (Hanson, Larson, \& Snowdon, 1976; Swenson \& Vogel, 1983). Tho- 
se models led Kirschbaum, Pirke, and Hellhammer (1993) to develop the Trier Social Stress Test (TSST), an experiment that consists of public speaking exposure and a mental arithmetic task. The main goal of the TSST was to produce similar reactions induced by real social stressful situations and to allow for such investigation in human samples. Therefore, when a subject was attending both TSST phases, emotional, cognitive, and especially physiological and biological stress responses were elicited.

Although the effects generated by a stressful situation might significantly vary due to individual differences, studies with both clinical and non-clinical samples were conducted with the TSST and confirmed that the task produced a substantial stress load verified by distinct psychological and physiological measurements (Ellenbogen, Hodgins, Walker, Couture, \& Adam, 2006; Therrien et al., 2010; Wiemers, Schoofs, \& Wolf, 2013). These measurements usually include the assessment of subjective stress perception by self-report questionnaires (e.g., The Perceived Stress Scale; Kudielka, Buske-Kirschbaum, Hellhammer, \& Kirschbaum, 2004), as well as heart rate and stress hormones variations during the task. For these reasons, the TSST has been widely used as an innovative tool in the investigation of neuroendocrine patterns associated with psychological stress exposure, including reports that assessed the hypothalamic-pituitaryadrenal (HPA) axis functioning by cortisol, and adrenocorticotropin hormones levels analysis (Dickerson \& Kemeny, 2004). In addition, a meta-analysis that included 208 human laboratory studies showed that public speaking/cognitive mental task (mental arithmetic performance) combination is associated with greater stress response than other types of stress inoculation protocols (Dickerson \& Kemeny, 2004), suggesting that the cognitive performance evaluation associated with the presence of social evaluation increase the stressful situation.

Because of limited knowledge on stress-induced alterations during childhood, the authors that proposed the primary version adapted the TSST for children samples a few years later (Buske-Kirschbaum et al., 1997). In the experi- ment, a committe of judges conducted by two or three researches performs two tasks whith participants. First, children receive the beginning of a story and must finish telling the story with as much excitement as possible in front of the committee for five minutes. Second, the participant is then asked to serially subtract the number 7 from 758 as quickly and as accurately as possible. On every failure during arithmetical task, the participant should restart from the beginning.

The adaptation of the TSST for children represented an important advancement in both stress and child development research, resulting in the publication of a series of studies with a standard experimental method. Nevertheless, we could not find a Brazilian version of the TSST for children, although the adaptation of this protocol may provide an innovative tool for Brazilian research on psychological stress consequences. Thus, the aim of this study was to translate and adapt the TSST protocol for children to the Brazilian Portuguese language.

\section{Method}

The study methods consisted of the translation and adaptation steps of the task, which were conducted accordingly with the Sousa and Rojjanasrirat (2011) method. The first step was the translation of the story told to children in the public speaking phase of the task, from English to Brazilian Portuguese. Two researchers proficient in English and Portuguese made translated the story text (S1). This version was sent to a bilingual specialist so that any necessary corrections could be made, resulting in the final version (FS). In this step, we prioritized the semantic equivalence between the first and second translations and the perspective of referential meaning terms regarding particular words.

The second step consisted of the standardization of the stages of the protocol. The experiment's pre and post phase descriptions were also adapted to Brazilian Portuguese by two researchers (P1) and, therefore, send to two (a psychologist and a psychiatrist) experts in the stress, child development and experimental psychology research field. After that, the final 
version of TSST for children stages' description (FP) was established. In the standardization process, we prioritized a clear and objective description of each step of the protocol, although some pre and post phases might vary according to aims of the studies. In addition, it is important to note that the original TSST does not have a standard rapport. Therefore, two psychology researchers produced a rapport text for the Brazilian version (R1), which was analyzed by the same two experts cited above. Thus, the rapport text final version was established (FR).

In the third and final step, the final version was shown to five children with ages ranging from 7 to 11 years ( 2 girls and 3 boys; mean age $9 \pm 1.4$ years and $4 \pm 1.5$ years of formal education). These children were recruited by random sampling of a private school, according consent of their parents. We created an interview to assess how understandable the TSST Brazilian version was to children. A verbal five-point scale was used for each question of the interview. The questions were as follows: "Did you understand what the story told?" (Q1). The minimum value was "0" (e.g., "Not at all") and the maximum value was " 5 " (e.g., "I understand perfectly and I have no doubt"); "Could you tell an end to the story?" (Q2), and "Could you perform the mathematical calculations?" (Q3). Because of the adaptation process we also opted to investigate children's interest about the story by means of two questions, "Did you like the story?" (Q4) and "Did you find the story interesting?" (Q5). The interview was conducted by a researcher with experience in children management. In addition, the interviewer explained the experiment goals to children and that the participants will be evaluated by a committee of judges while performing the task. In order to collect suggestions or criticisms regarding the instrument, for each question the children were encouraged to make comments about what was asked. Finally, the children's comments were evaluated according to the relevance for the processes of adaptation, and some of them are described in detail.

\section{Results}

The results are summarized in two tables and one figure. The translation and adaptation processes of the free speech story are presented in Table 1, including the FS. The standardization of the remaining stages of the protocol, including the rapport, is presented in Table 2 and illustrated in Figure 1.

Table 1

Description of the Translation and Adaptation Process of the Story Text

Original Story Text Yesterday my best friend Robert and I went home from school. Suddenly, we had the idea to visit Mr. Greg who lived in the big old house located in the dark forest near our town. Mr. Greg was a crazy old man and our parents didn't like the idea that we sometimes went visiting him. There was a rumor in town that there was a mystery about the old house. When we arrived at the house we were surprised that the door was open. Suddenly we heard a strange noise and cautiously, we entered the dark hall.

Translated Story Ontem, meu melhor amigo Robert e eu fomos para casa saindo da escola. De repente, tivemos Text (S1) a ideia de visitar o Sr. Greg, que vivia em uma grande casa velha localizada em uma floresta escura próxima da nossa cidade. Sr. Greg era um velho louco e nossos pais não gostavam da ideia de, às vezes, irmos visitá-lo. Havia um boato na cidade de um mistério sobre a casa velha. Quando chegamos na casa, ficamos surpresos que a porta estava aberta. De repente, nós escutamos um barulho estranho e, cuidadosamente, entramos na sala escura...

Final Version (FV) Ontem, eu e meu melhor amigo Roberto fomos para casa saindo da escola. De repente, tivemos a ideia de visitar o Sr. Jorge, que vive em uma grande casa velha localizada em uma floresta escura, próxima da nossa cidade. O Sr. Jorge é um velho louco e nossos pais não gostam da ideia de, às vezes, irmos visitá-lo. Havia um boato na cidade sobre um mistério envolvendo a casa velha. Quando chegamos na casa, ficamos surpresos que a porta estava aberta. De repente, nós escutamos um barulho estranho e, com muito cuidado, entramos na sala escura... 
During the translation of the story there were only two issues that required semantic alterations. First, the sentence "There was a rumor in town that there was a mystery about the old house" was translated to "Havia um rumor na cidade que havia um mistério sobre a casa velha" in the S1. However, this sentence was modified to "Havia um boato na cidade sobre um mistério envolvendo a casa velha" in the FS in order to make it easier to comprehend for younger children. Second, the character names "Robert" and "Greg" were altered to "Roberto" and "Jorge" with the purpose of cultural adaptation to Brazil.

In the standardization of the stages of the protocol, some modifications between P1 and FP were realized. The P1 described the Baseline phase as the moment in which the heart rate monitor could be inserted and initiated. In the FP, however, it was added as supplementary information regarding physiological and biological measurements, because TSST is often used for investigations of endocrine's markers. Furthermore, the R1 Explanation phase rapport ("Agora, você vai ouvir uma história e, logo após, finalizá-la de modo que consiga torná-la o mais interessante possivel, pois ela será avaliada por uma banca de juizes") was changed to "Agora, vou lhe contar o trecho inicial de uma história e você deverá continuar esta história de modo que consiga torná-la o mais interessante e criativo possivel para que os juizes lhe avaliem" in the FR. The reasoning behind this alteration was to make the sentence more habitual to children's language. In the same way, the beginning of the rapport ("você vai ouvir uma história") was altered to "vou lhe contar o trecho inicial de uma história." In addition, the word "criativo" was added on the rapport to encourage children to detail and increase the elements of the speech, avoiding short stories. The utterance "banca de juizes" was also modified to "juizes" in order to simplify the information. Moreover, one last sentence was added on the rapport: "O final que você criou será comparado com o de outras crianças como se fosse um concurso de histórias" with the purpose of increasing children's interest and involvement with the idea that the task is also a contest.

There were also the following alterations during the rapport-making process. The R1 judge's speech ("Por favor, você pode começar") was modified to "Tudo bom participante? Pode começar a sua história" in order to make the task a little less frightening, ultimately preventing the child from quittin the experiment at the beginning. Furthermore, the R1 word "enriquecer" was substituted by the sentence "colocar mais detalhes" in the FR, in order to avoid the children's assumption that to "earn money" was an additional aim of the task.

\section{Table 2}

Description of the TSST for Children Protocol Phases

Baseline

Explanation Phase
O pesquisador encaminha a criança para uma sala acompanhada de seu responsável. Este momento é apropriado para a realização de entrevistas de acordo com os objetivos do estudo. Além disso, pode-se avaliar o estado de repouso fisiológico do participante, através de medidas biológicas (e.g. swab oral elou sangue periférico) elou verificação da frequência cardíaca.

Após 20 minutos, a criança sozinha é encaminhada pelo primeiro pesquisador para uma sala onde acontecerá a atividade. Nesta sala, os dois juízes já estarão aguardando, posicionados atrás de uma mesa e de posse dos materiais que serão utilizados (gravador, câmera de vídeo, microfone), com intuito de tornar o ambiente o mais realista possível. Neste primeiro momento, a criança apenas faz o reconhecimento do local onde ocorrerá a atividade. A criança então é deslocada para uma nova sala, onde apenas permanecem ela e o primeiro pesquisador. A partir disso, dá-se início ao rapport: "Agora, vou lhe contar o trecho inicial de uma história (Tabela 1) e você deverá continuar esta história de modo que consiga torná-la o mais interessante e criativo possivel para que os juizes lhe avaliem. Além disso, ofinal que você criou será comparado com o de outras crianças como se fosse um concurso de histórias". 
Preparation Phase $\quad$ O pesquisador deixa a criança sozinha em outra sala e ela terá um periodo de 5 minutos para preparar a continuação da história.

Free Speech Após esse tempo, a criança é novamente encaminhada para a sala onde estão os juízes e inicia-se a fase de fala livre. Cabe salientar que o pesquisador não acompanha a criança dentro da sala onde acontece a atividade. Um dos juizes então instrui o participante a dar início à sua história - "Tudo bom participante, pode começar a sua história". Deste modo, a criança deverá se posicionar na frente do microfone e contar o seu final criado em no máximo 5 minutos. Caso a criança termine a história em menos de 5 minutos, ela pode ser encorajada a continuar de forma imparcial - "Ainda temos tempo, você pode continuar ou colocar mais detalhes na sua história".

Mental Arithmetic Neste momento os juizes solicitam que a criança subtraía, serialmente, o número 7 de 758 o mais rápido e precisamente possível. Cada vez que a criança errar, um dos juizes intervém, solicitando que a criança inicie novamente os cálculos a partir do número inicial (758) "Pare. Por favor, comece novamente". Diferentemente da versão do TSST para adultos, os membros da banca podem dar feedback positivo para o participante, seja ele verbal ou facial.

Feedback Phase É o periodo no qual se discute com a criança a intensidade do estresse experienciado ao realizar a tarefa, informando a ela que seu desempenho foi superior ao das outras crianças. Após esse período, pode-se realizar novas avaliações biológicas ou nova verificação de frequência cardiaca. Assim, encerra-se o protocolo e ela é entregue aos familiares ou responsáveis.

The questions regarding children interest and comprehension of the story presented a mean score of up to 4 points in the verbal fivepoint scale, Q1 (mean 3 \pm 1), Q4 (mean 2.8 \pm 1.7 ) and Q5 (mean 1.8 \pm 1.4 ). The questions about the task's difficulty presented lower means in comparison with the other questions, Q2 (mean 3.6 .8 ) and Q3 (mean 3.2 \pm 1.7 ). Regarding children comments, there were three important notes. First, when the Q2 was presented to a child the following observation was made: "I am able to think about some ending, but I think that it will be difficult to tell since I would have felt nervous". Second, when the Q5 was presented another child made the comment: "These calculations are harder to solve without a scratch leaf, we often use that at school," thus for the FP, it was chose to only use the arithmetic calculation that initiates with 758 . In addition, one child reported that: "Speaking in front of strangers is hard, I guess in both parts", suggesting the idea of social evaluation as an important challenge. Finally, three children asked if the story has an ending and if their story was correct.

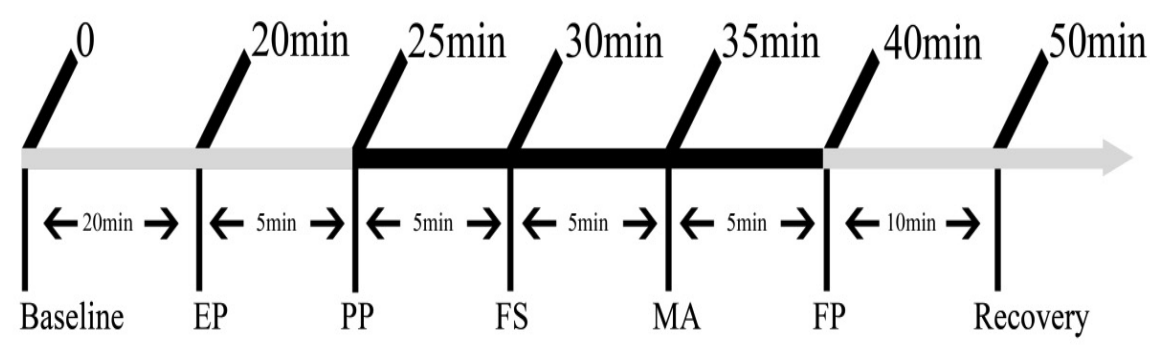

EP: Explanation Phase; PP: Preparation Phase; FS: Free Speech; MA: Mental Arithmetics; FP: Feedback Phase.

-Stress Inoculation

Figure 1. Illustration of the TSST for children protocol phases. 


\section{Discussion}

The current study sought to translate and adapt the TSST for children to the Brazilian Portuguese language. The final version of the protocol consists of a story regarding the public speaking phase, as well as instructions about each phase of the protocol, that includes rapports and information concerning the pre and the post stages of the TSST. Based on our results, the adapted TSST for children might be a method to induce psychological stress in the intended population. The children reported that both tasks, the public speaking exposure and the mental arithmetic, cannot be easily done. In addition, they believe that the reasons that the TSST causes stress for them are the difficulty of the tasks and the requirement to perform these tasks in front of a committee of judges. These reports meet the major aim of the original TSST, which is to induce psychological stress in human subjects through both cognitive performance evaluation and social evaluation.

It should be noted that this study has some limitations, given the small number of children judges, as well as the restricted age range of the judges. Therefore, it seems worthwhile to investigate the reliability of the Brazilian TSST for children in larger samples that also encompass children of other ages in future investigations. Furthermore, a pilot study is probably necessary to investigate physiological measurements and the HPA activation in response to the psychological stress elicited by the Brazilian's version of the protocol. A validation study is also necessary for the Brazilian population, especially regarding the mental arithmetic task, since cultural differences may affect the test complexity and we cannot predict how the Brazilian children will behave during the arithmetic task. Also, regarding the stress elicited by this task, some ethical issues should be considered in conducting a research with the TSST for children. In this sense some international studies reported the realization of short debriefing sessions immediately after the completion of the study, giving complete insight into the nature of the experiment (Youssef et al., 2012).
Psychological stress research is a difficult matter, especially because it is extremely complex to study during childhood. However, only a few researchers have described the use of strategies and steps for the adaptation and validation of instruments, and even less for the purposes of cross-cultural adaptation of experimental methods (Sousa \& Rojjanasrirat, 2011). Even so, it is strongly recommended that the adaptation procedure should consist of a comprehensive method that involves not only the translation, but also the adaptation and evaluation of the instrument's particularities. Therefore, a standardized method can reduce behavioral uniformities and also increase the efficiency and accuracy of the investigation with the TSST. There is an urgent need for the development of novel research technologies in Brazilian science. By offering a new tool of investigation, this work is building toward innovation in the Brazilian stress research field. The adaptation of the TSST for children is in agreement with the idea that it is necessary to improve the scientific and technological methods regarding psychological research.

Finally, it is worth it to emphasize that the validation study of the Brazilian version of the TSST for children is already in progress. In addition, whereas research on stress also involves physiological and biological markers and measurements, the TSST is also an innovative tool for multidisciplinary research.

\section{References}

Ackerman, K. D., Martino, M., Heyman, R., Moyna, N. M., \& Rabin, B. S. (1996). Immunologic response to acute psychological stress in MS patients and controls. Journal of Neuroimmunology, 68(1-2), 85-94. doi:10.1016/01655728(96)00077-X

Al'Absi, M., Bongard, S., Buchanan, T., Pincomb, G. A., Licinio, J., \& Lovallo, W. R. (1997). Cardiovascular and neuroendocrine adjustment to public speaking and mental arithmetic stressors. Psychophysiology, 34(3), 266-275.

Buske-Kirschbaum, A., Jobst, S., Wustmans, A., Kirschbaum, C., Rauh, W., \& Hellhammer, D. (1997). Attenuated free cortisol response to psychosocial stress in children with atopic dermatitis. Psychosomatic Medicine, 59(4), 419-426. 
Cacioppo, J. T., Malarkey, W. B., Kiecolt-Glaser, J. K., Uchino, B. N., Sgoutas-Emch, S. A., Sheridan, J. F., ...Glaser, R. (1995). Heterogeneity in neuroendocrine and immune responses to brief psychological stressors as a function of autonomic cardiac activation. Psychosomatic Medicine, 57(2), 154-164.

Cirulli, F., Francia, N., Berry, A., Aloe, L., Alleva, E., \& Suomi, S. J. (2009). Early life stress as a risk factor for mental health: Role of neurotrophins from rodents to non-human primates. Neuroscience \& Biobehavioral Reviews, 33(4), 573-585. doi:10.1016/j.neubiorev.2008.09.001

Danese, A., \& McEwen, B. S. (2012). Adverse childhood experiences, allostasis, allostatic load, and age-related disease. Physiology \& Behavior, 106(1), 29-39. doi:10.1016/j.physbeh.2011.08.019

Dhabhar, F. S. (2013). Psychological stress and immunoprotection versus immunopathology in the skin. Clinics in Dermatology, 31(1), 18-30. doi:10.1016/j.clindermatol.2011.11.003

Dickerson, S. S., \& Kemeny, M. E. (2004). Acute stressors and cortisol responses: A theoretical integration and synthesis of laboratory research. Psychological Bulletin, 130(3), 355-391. doi:10.1037/0033-2909.130.3.355

Ellenbogen, M. A., Hodgins, S., Walker, C. D., Couture, S., \& Adam, S. (2006). Daytime cortisol and stress reactivity in the offspring of parents with bipolar disorder. Psychoneuroendocrinology, 31(10), 1164-1180. doi:http://dx.doi. org/10.1016/j.psyneuen.2006.08.004

Galvan, A., \& Rahdar, A. (2013). The neurobiological effects of stress on adolescent decision making. Neuroscience, 249, 223-231. doi:10.1016/j. neuroscience.2012.09.074

Grassi-Oliveira, R., Ashy, M., \& Stein, L. M. (2008). Psychobiology of childhood maltreatment: Effects of allostatic load? Revista Brasileira de Psiquiatria, 30(1), 60-68. doi:http://dx.doi. org/10.1590/S1516-44462008000100012

Hanson, J. D., Larson, M. E., \& Snowdon, C. T. (1976). The effects of control over high intensity noise on plasma cortisol levels in rhesus monkeys. Behavioral Biology, 16(3), 333-340.

Kirschbaum, C., Pirke, K. M., \& Hellhammer, D. H. (1993). The 'Trier Social Stress Test'--A tool for investigating psychobiological stress responses in a laboratory setting. Neuropsychobiology, 28(1-2), 76-81. doi:10.1159/000119004
Kudielka, B., Buske-Kirschbaum, A., Hellhammer, D., \& Kirschbaum, C. (2004). HPA axis responses to laboratory psychosocial stress in healthy elderly adults, younger adults, and children: Impact of age and gender. Psychoneuroendocrinology, 29(1), 83-98.

McEwen, B. S. (2012). Brain on stress: How the social environment gets under the skin. Proceedings of the National Academy of Sciences of the United States of America, 109(Suppl. 2), 1718017185. doi:10.1073/pnas.1121254109

Sousa, V. D., \& Rojjanasrirat, W. (2011). Translation, adaptation and validation of instruments or scales for use in cross-cultural health care research: A clear and user-friendly guideline. Journal of Evaluation in Clinical Practice, 17(2), 268-274. doi:10.1111/j.1365-2753.2010.01434.x

Swenson, R. M., \& Vogel, W. H. (1983). Plasma Catecholamine and corticosterone as well as brain catecholamine changes during coping in rats exposed to stressful footshock. Pharmacology Biochemistry \& Behavior, 18(5), 689-693.

Therrien, F., Drapeau, V., Lalonde, J., Lupien, S. J., Beaulieu, S., Dore, J., ...Richard, D. (2010). Cortisol response to the Trier Social Stress Test in obese and reduced obese individuals. Biological Psychology, 84(2), 325-329. doi:10.1016/j. biopsycho.2010.03.013

Wiemers, U. S., Schoofs, D., \& Wolf, O. T. (2013). A friendly version of the Trier Social Stress Test does not activate the HPA axis in healthy men and women. Stress, 16(2), 254-260. doi:10.3109 $/ 10253890.2012 .714427$

Yehuda, R., \& Seckl, J. (2011). Minireview: Stressrelated psychiatric disorders with low cortisol levels: A metabolic hypothesis. Endocrinology, 152(12), 4496-4503. doi:10.1210/en.2011-1218

Youssef, F., Dookeeram, K., Basdeo, V., Francis, E., Doman, M., Mamed, D., ...Legall, G. (2012). Stress alters personal moral decision making. Psychoneuroendocrinology, 37(4), 491-498. doi:10.1016/j.psyneuen.2011.07.017

Received: March, 12, 2013

$1^{\text {st }}$ revision: November, 06, 2013

$2^{\text {nd }}$ revision: November, 21, 2013

Accepted: November, 27, 2013 